\title{
LITERATURA SURDA: EXPERIÊNCIA DAS MÁOS LITERÁRIAS, DE CLÁUDIO HENRIQUE NUNES MOURÃO $^{1}$
}

\author{
Marcela Dezotti Cândido \\ Universidade Federal de Minas Gerais, UFMG, Belo Horizonte, MG, Brasil
}

A tese "Literatura surda: experiência das mãos literárias", de Cláudio Henrique Nunes Mourão, tem como objetivo refletir sobre a trajetória de construção de uma literatura por surdos em línguas de sinais. No início do texto, o autor contextualiza a Literatura Surda no Brasil, explicando que, embora houvesse uma prática informal de literatura em línguas de sinais nas escolas de surdos, os estudos sobre cultura surda são recentes no país e foram iniciados nos últimos vinte anos. Em seguida, apresenta suas experiências acadêmicas, além de sua participaçáo em eventos sobre arte e língua de sinais, vivências que justificam a escolha do tema de sua pesquisa.

As bases teóricas da investigaçáo incluem os Estudos Culturais e os Estudos Surdos, com contribuiçóes de pesquisadores como Wrigley (1996), Hall (2007; 2011), Larrosa (2015), dentre outros. Mourão contextualiza o surgimento dos Estudos Culturais e sua chegada ao Brasil na década de 1990, no campo da Educação da UFRGS. Com relação aos Estudos Surdos, aponta que se constituíram como uma área de pesquisa na mesma instituição, com foco na diferença cultural surda, de modo a significar o ser surdo, distanciando-o de discursos ligados à normalização, à padronização e ao ouvintismo.

Posteriormente, o pesquisador aborda o conceito de literatura e discute seus diferentes significados. Para isso, apresenta distintas definiçóes elaboradas por teóricos, além de citar as entrevistas realizadas com surdos em sua pesquisa, uma vez que os entrevistados apresentam conceitualizaçóes diferentes, o que pode ser decorrente das experiências que vivenciaram. $\mathrm{O}$ autor também discorre sobre a trajetória literária do povo surdo e tece uma perspectiva histórica sobre a educação dos surdos, o uso da língua de sinais

${ }^{1}$ Tese orientada pela Profa. Dra. Lodenir Becker Karnopp, defendida em 2016, na Universidade Federal do Rio Grande do Sul, Porto Alegre. 
e a transmissão de valores linguísticos e culturais, afirmando que a língua de sinais é um artefato cultural linguístico.

O corpus desse estudo é constituído por entrevistas realizadas com doze surdos que apresentavam protagonismo no cenário cultural, em que nove eram brasileiros e três estrangeiros - dois britânicos e uma alemá. De acordo com Mourão, a escolha em analisar representantes surdos brasileiros e estrangeiros proporciona o debate das experiências desses profissionais a partir de uma ampliação do cenário de experiências produzidas. As entrevistas foram realizadas tanto na modalidade à distância, via e-mail e/ ou Whats $A p p$, quanto na presencial. Os entrevistados se comunicaram por meio de LIBRAS ou Língua Internacional de Sinais, e apenas uma das entrevistadas interagiu em português escrito. Além de surdos, todos os participantes da pesquisa tinham experiência na área de Literatura Surda e haviam produzido algum material na língua de sinais.

As análises realizadas dão visibilidade à Literatura Surda e às experiências de surdos em mãos literárias e revelam como os participantes da pesquisa utilizam o conceito de Literatura Surda e Língua de Sinais, com evidência de utilização das mãos literárias entre os surdos em oficinas, congressos, festivais, apesar de a maioria dos entrevistados desconhecerem o significado de Literatura Surda no espaço social e educacional decorrente de poucos profissionais na área. As experiências dos entrevistados ocorreram, desse modo, por meio de sua formaçáo literária, e foram sendo absorvidas pela sua identificação cultural e pelo seu pertencimento à comunidade surda. Com relaçáo à representaçáo da Literatura Surda, os entrevistados a conectaram aos efeitos estéticos ligados à visualidade com características da identidade surda por meio da tradição do povo surdo.

Por fim, o resultado do estudo salienta a importância da ampliação e da distribuiçáo dos conhecimentos das mãos literárias, nos espaços escolares e universitários, e a necessidade de transmitir para a sociedade os valores e a riqueza cultural da Literatura Surda, a fim de visibilizar a cultura surda e de contribuir para a promoção da educação para surdos. 